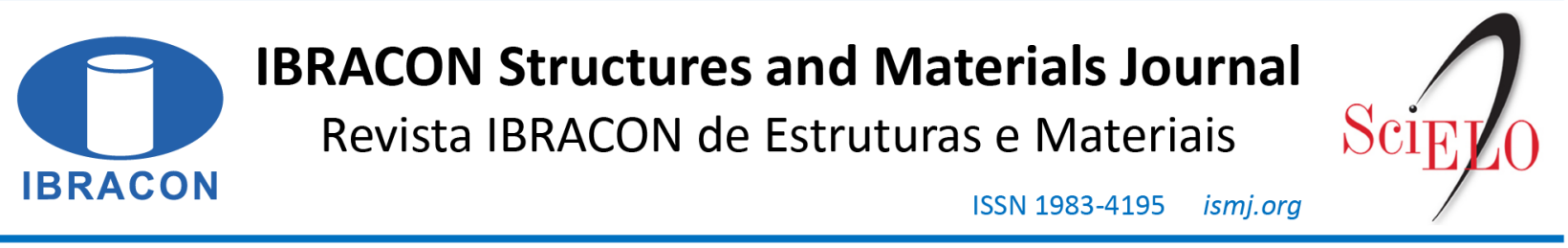

ORIGINAL ARTICLE

\title{
Increasing structuration rate of 3D printable concretes: the effect of viscosity enhancing admixtures
}

\section{Elevação da taxa de estruturação de concretos para impressão 3D: o efeito de aditivos modificadores de viscosidade}

Jessica Amanda Hasse ${ }^{a}$ (D)

Ariane Prevedello Rubin ${ }^{\mathrm{a}}$ (i)

Lucas Carvalho Quintanilha ${ }^{\mathrm{a}}$

Wellington Longuini Repette ${ }^{\mathrm{a}}$ (D)

${ }^{a}$ Universidade Federal de Santa Catarina - UFSC, Departamento de Engenharia Civil, Florianópolis, SC, Brasil

Received 06 November 2019

Accepted 04 February 2020

\begin{abstract}
In the last decades, 3D printing has emerged as a promising new paradigm for manufacturing. Even in the civil construction industry, it has gained attention from companies and researchers around the world. Despite of that, the properties of materials applied in the additive manufacturing process are still understudied. One of the challenges is the need to conciliate both high bearing capacity, sparing the need of any confining measures, and the ability of keeping fluidity for enough time, in order to avoid cold joints between the layers. In that scenario, viscosity enhancing admixtures (VEAs) can be a solution, because they are able of promoting flocculation, viscosity gain and yield strength increase, reducing the deposition time in between the layers, which may decrease the formation of cold joints. This research evaluated rheological parameters of four different VEAs and found out that they show potential for increasing the cohesion and buildability of concretes for 3D-printing. The results showed that this effect varies with the type and amount of the admixture adopted and bentonite clay, as a mineral powder material, performed best in comparison to other polymeric VEAs, presenting structuration rates of up to $62 \%$ higher than the reference mixture.
\end{abstract}

Keywords: 3D printing, additive manufacturing, extrudable concrete, viscosity-enhancing admixtures, bentonite clay.

\begin{abstract}
Resumo: Nas últimas décadas, a impressão 3D emergiu como um novo e promissor paradigma de fabricação. Mesmo na indústria da construção civil, ela tem ganhado atenção de empresas e pesquisadores de todo o mundo. Apesar disso, as propriedades dos materiais aplicados no processo de manufatura aditiva ainda são pouco estudadas. Um dos desafios está na necessidade de conciliar alta capacidade portante, poupando a necessidade de quaisquer medidas restritivas, com a capacidade de manter a fluidez por tempo suficiente, a fim de evitar juntas frias entre as camadas. Nesse sentido, os aditivos Modificadores de viscosidade (VMAs) podem ser uma solução, pois são capazes de promover floculação, ganho de viscosidade e aumento da tensão de escoamento, reduzindo o tempo de deposição entre as camadas, o que pode diminuir a formação de juntas frias. Esta pesquisa avaliou parâmetros reológicos de quatro VMAs diferentes e descobriu que eles apresentam potencial para aumentar a coesão e a construtibilidade de concretos para impressão 3D. Os resultados mostraram que esse efeito varia com o tipo e a quantidade de aditivo adotado. Particularmente, a argila bentonita, como aditivo mineral em pó, apresentou melhor desempenho em comparação com os VMAs poliméricos, produzindo taxas de estruturação até $62 \%$ superiores à mistura de referência.
\end{abstract}

Palavras-chave: impressão 3D, manufatura aditiva, concretos extrudáveis, aditivos modificadores de viscosidade, argila bentonita

How to cite: J. A. Hasse, A. P. Rubin, L. C. Quintanilha, and W. L. Repette, "Increasing structuration rate of 3D printable concretes: the effect of viscosity enhancing admixtures", Rev. IBRACON Estrut. Mater., vol. 13, no. 4, e13412, 2020, https://doi.org/10.1590/S1983-41952020000400012 


\section{INTRODUCTION}

The additive manufacturing technology, or simply 3D printing, dates back to the 1980 s and it was initially developed in the scope of prototyping [1]. In the last two decades, however, there has been a growing interest around the additive fabrication processing of large-scale components for civil construction. The technique can be used to optimize time, reduce costs, flexibilize projects, reduce waste generation, and fabricate structures without formwork and falsework [2]-[5].

However, in the additive manufacturing process with concrete, the challenge of stacking layers tightly attached to one another still persists. If the layers overlaps occur too quickly, they won't have sufficient strength to avoid deformations caused by their own weight. On the other hand, if optimal waiting time between depositions is exceeded, there will be loss of interlayer adhesion and formation of cold joints, which compromises the final mechanical performance of the structure [3], [6].

The stability of the printed structure depends on two distinct factors: (a) the vertical stress acting on the prior deposited layers and (b) the material's yield strength. Both are time dependent, being the former related to the construction rate, i.e. the speed at which each new layer is deposited after the previous layer, while the latter relates to the structuring at rest of the concrete [3], [6].

\subsection{Extrudable concretes}

In recent years, 3D printing systems have been successfully applied to the construction of structural elements and architectural components, adopting a variety of cementitious compositions. However, there is still no domain or consensus in the technical-scientific community regarding the preparation of cementitious mixtures suitable for additive manufacturing [1], [4], [7]. Among the main objects of study in this matter are the topics related to the properties at the fresh state of the material, mainly extrudability and buildability.

Extrudability refers to the ability of the material to continuously flow through the tubes and nozzles in the print head, and it is measured based on the distance by which the concrete can be printed without blocking the nozzle, free from cracks and separations. Buildability refers to the ability of the material to maintain the extruded shape under its own weight and the stresses from the upper layers and it can be measured by the maximum number of printed layers without collapse [2], [4], [6]. The maintenance of desirable properties can be obtained by using chemical admixtures capable of adjusting the mixture's desired workability. Note that the material must be sufficiently fluid for extrusion purposes, but sufficiently firm for mechanical stability of the structure. For this reason, the influence of several admixtures on such material is the subject of lots of recent studies [4], [8].

\subsection{Structuration rate}

The resting time between the casting of two successive layers is directly related to the development of the microstructure of the cementitious material. This process depends basically on: (a) a reversible physical phenomenon, due to the flocculation processes of the colloidal particles, and (b) an irreversible chemical phenomenon, due to the hydration processes in the cement paste [9]-[11], promoting an increase on the materials yield strength, but also diminishing its workability throughout the resting time [12]-[15].

In this context, the yield strength can be defined as the ability of the cementitious material to withstand the stresses, resulting from the attractive interparticular forces between cement and the other particles that constitute the mixture. Therefore, to ensure the stability of the printed structure, fresh concrete yield strength, over resting time, must increase and be greater than the imposed stresses [9].

The materials yield strength evolution over resting time, during the flocculation period of cementitious matrices, follows a linear regimen, previously denominated as structuration rate (Athix) and may be estimated be estimated by the following equation from [13]:

Athix $=(\tau 0(t)-\tau 00) / t$

Where: Athix is the structuration rate $(\mathrm{Pa} / \mathrm{s}) ; \tau 0(\mathrm{t})$ is the yield strength after some time $(\mathrm{Pa}) ; \tau 00$ is the initial yield strength $(\mathrm{Pa})$; and $\mathrm{t}$ is the elapsed time (s). 


\subsection{Viscosity enhancing admixtures}

One way to control the rheological behavior of cementitious matrices is by the use of viscosity enhancing admixtures (VEAs), which are generally applied to concretes in order to reduce the risk of segregation and exudation [16]-[18]. Since their action increases the viscosity and yield strength of the mixtures, their use may be extended to printable concretes [7].

There are many types of VEAs, which can be mineral compounds in the form of extremely fine powders (such as silica fumes and nanoclays), natural polymers (xanthan gum and agar) and synthetic or semi-synthetic polymers (polyacrylates, polyvinyls, ether derivatives) [16], [17]. Similarly, the actuation mechanism of such additives may also vary [7]. It is evident that the extent of viscosity increase will depend on the type and concentration of the admixture, its adsorption capacity by the cement particles, anionicity and molecular weight [19], as well as the shear rate applied to the concrete. The modes of action of the main polymeric VEAs, according to [17], are:

- Adsorption: Long-chain polymer molecules adhere to water molecules, fixating it in part and expanding so that the viscosity of the liquid medium in the mixture is increased.

- Association: Polymer molecules develop attractive forces with each other so that, when connected, they block the free passage of water from the mixture. This promotes gel formation with consequent increase in viscosity.

- Intertwining: At higher concentrations, polymeric molecules can intertwine and entangle, increasing the viscosity of the assembly in which they fit. This effect can disappear at sufficiently high shear rates by aligning the polymer chains in the flow direction, generating a behavior known as pseudoplasticity.

Since these admixtures have a potential increase in the yield strength of concrete, their insertion may be able to improve the structuring rate of mixtures intended for 3D printing. However, because of the variability of types and modes of operation, especially with regard to polymeric VEAs, it is important to evaluate the various commercially available products.

\subsection{Bentonites}

Mineral compounds in the form of fine powders are among the most used viscosity enhancing admixtures for concrete. Among them, but not so disseminated, nanoclays and, particularly, bentonite clays arouse special interest because of their unique properties, such as the capacity of producing thixotropic gels, expanding up to 20 times its original volume when put in contact to water [20], [21].

Due to the high concentration of adsorbed cations over the clay particle surface, when the particles are dispersed in a liquid, the diffusion phenomenon happens so to equalize the concentration all over the fluid. However, the ease to which this should happen depends on the electromagnetic field originated around the particle' surface, and also on the ion-surface interactions that are unique to every type of exchangeable cation. The phenomenon caused by the combination of these two opposite events is called diffuse double layer [22], [23].

It is known that the montmorillonite particles are extremely small, flats and floc shaped, with $1 \mathrm{~nm}$ of thickness by $220 \mathrm{~nm}$ of length, and have two different charges on its surfaces. On the face of the particle a negatively charged surface occurs, resulted from the isomorphic replacements that occur internally with the cations on the crystal lattice. On the other hand, on the borders of the particles a $\mathrm{pH}$ dependent surface is formed, resulted from the protonation and deprotonation of the $\mathrm{OH}^{-}$groups, varying from positive to negative as the solution $\mathrm{pH}$ is altered [24], [25].

Figure 1 shows the behavior of the clays when dispersed in a fluid. When submitted to a forced flow, particles tend to orientate according to the flow. When the flow is discontinued, particles are rearranged by the attraction of the negatively charged faces to the positively charged extremities, forming a tridimensional structure inside the fluid [26].

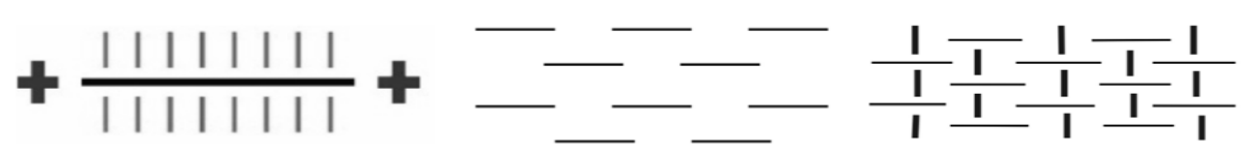

Figure 1. Bentonite clays behavior: charged particle, under forced flow and at rest [Zhang et al., 2018].

The unique thixotropic gels formation in these materials is then produced by this combination of effects, where the electro-viscous effect under low ionic forces, caused by the well-developed diffuse double layer, is later kept by 
the particle immobilization on the tridimensional formed net. Besides that, particles that have opposite charged to the clay-minerals, i.e. the oxides from the iron and aluminum hydroxides, also favor the thixotropic tendency of the solutions through the formation of connection points between them [21], [25].

When interacting, bentonite clays and cement may alter the mixes properties by three different reasons: the significant increase in the $\mathrm{pH}$ solution (around $12 \sim 13$ caused by the cement), would promote the thixotropic gels formation from the alteration of the charges on the bentonite particles ends, the supersaturation of $\mathrm{Ca}^{2+}$ ions, which may favor or prejudice the cation exchange, depending on the bentonite nature, as well as promote a higher water retention between the particle's layers, compressing the double diffuse layer for the high ion concentration that will result in higher flocculation, and a somewhat meaningful presence of $\mathrm{K}^{+}$ions. All of these effects would promote the retention of water, significantly increasing the viscosity of the mixture [27].

\section{MATERIALS AND EXPERIMENTAL PROGRAM}

In this context, the present work analyzes the effect of different viscosity enhancing admixtures in extrudable concretes and their influence in the materials' yield strength over time, in order to favor its structuration rate (Athix), required to improve buildability of printable mixtures.

\subsection{Materials and mixture proportions}

For this research, nine different mixtures were produced as stated in Table 1: one reference mixture (without any VEA content), and eight other mixtures with four different types of VEA in two amounts (three polymeric commercial VEAs and one type of bentonite clay). All of them were made with Portland cement with pozzolanic addition, classified as CP-IV, according to ABNT NBR 5736/1991 [28]. Table 2 presents the chemical composition of the adopted powder materials. The granulometric composition measured with a Microtrac S3500 laser granulometer of the dry materials is shown in Figure 2.

Table 1 Mixes proportioning.

\begin{tabular}{|c|c|c|c|c|c|c|c|c|c|}
\hline Mix & $\begin{array}{c}\text { Portland } \\
\text { cement } \\
\left(\mathrm{Kg} / \mathrm{m}^{3}\right)\end{array}$ & $\begin{array}{c}\text { Fine sand } \\
\left(\mathrm{Kg} / \mathrm{m}^{3}\right)\end{array}$ & $\begin{array}{c}\text { Water } \\
\left(\mathrm{Kg} / \mathrm{m}^{3}\right)\end{array}$ & $\begin{array}{c}\text { Silica } \\
\text { fume } \\
\left(\mathrm{Kg} / \mathbf{m}^{3}\right)\end{array}$ & $\begin{array}{c}\text { HRWR } \\
(\% *)\end{array}$ & $\operatorname{VEA1}(\% *)$ & VEA2 (\%*) & $\begin{array}{l}\text { VEA3 } \\
(\% *)\end{array}$ & $\begin{array}{l}\text { Bent } \\
(\% *)\end{array}$ \\
\hline REF & 706 & 1178 & 290 & 79 & 1.5 & - & - & - & - \\
\hline VEA1 0.6 & 706 & 1178 & 290 & 79 & 1.5 & 0.6 & - & - & - \\
\hline VEA1 1.2 & 706 & 1178 & 290 & 79 & 1.5 & 1.2 & - & - & - \\
\hline VEA2 0.6 & 706 & 1178 & 290 & 79 & 1.5 & - & 0.6 & - & - \\
\hline VEA2 1.2 & 706 & 1178 & 290 & 79 & 1.5 & - & 1.2 & - & - \\
\hline VEA3 0.6 & 706 & 1178 & 290 & 79 & 1.5 & - & - & 0.6 & - \\
\hline VEA3 1.2 & 706 & 1178 & 290 & 79 & 1.5 & - & - & 1.2 & - \\
\hline BENT 0.3 & 706 & 1178 & 290 & 79 & 1.5 & - & - & - & 0.3 \\
\hline \multirow[t]{2}{*}{ BENT 0.6} & 706 & 1178 & 290 & 79 & 1.5 & - & - & - & 0.6 \\
\hline & $*$ to th & ement weigl & & & & & & & \\
\hline
\end{tabular}

Table 2 Chemical composition of the powder materials.

\begin{tabular}{cccc}
\hline Determination & Cement (\%) & Silica Fume (\%) & Bentonite (\%) \\
\hline $\mathrm{SO}_{3}$ & 3.18 & 0.80 & - \\
\hline $\mathrm{Al}_{2} \mathrm{O}_{3}$ & 4.3 & $<0.04$ & 18.77 \\
\hline $\mathrm{SiO}_{2}$ & 18.96 & 84.87 & 61.22 \\
\hline $\mathrm{Fe}_{2} \mathrm{O}_{3}$ & 2.95 & 2.17 & 4.94 \\
\hline $\mathrm{MgO}$ & 3.26 & 1.98 & 3.69 \\
\hline $\mathrm{CaO}$ & 60.76 & 1.24 & 0.71 \\
\hline $\mathrm{K}_{2} \mathrm{O}$ & - & 2.49 & 0.50 \\
\hline $\mathrm{Na}_{2} \mathrm{O}$ & - & 1.18 & 1.41 \\
\hline $\mathrm{TiO}_{2}$ & - & 0.36 & - \\
\hline $\mathrm{Mn}_{2} \mathrm{O}$ & - & 1.98 & - \\
\hline $\mathrm{P}_{2} \mathrm{O}_{5}$ & $<0.01$ & - \\
\hline Insoluble residue & - & - & - \\
\hline $\mathrm{Heat}$ loss & 0.72 & 4.00 & - \\
\hline Free CaO & 3.45 & - & - \\
\hline Alkali equiv. & 0.75 & - & - \\
\hline
\end{tabular}




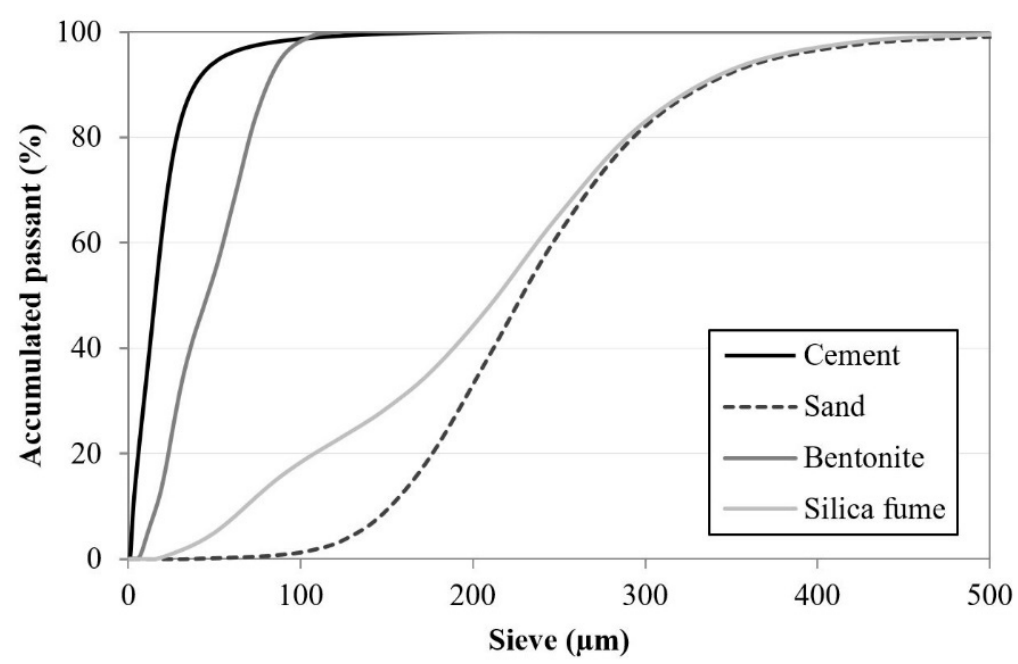

Figure 2. Gradation of the powder materials.

All mixtures were made using a polycarboxylate based high range water reducer admixture (HRWR). Also, besides bentonite clay, three commercial viscosity enhancing admixtures (denominated VEA1, VEA2 and VEA3) were investigated. Table 3 shows their main characteristics.

Table 3 Physical chemical characteristics for the admixtures.

\begin{tabular}{|c|c|c|c|c|}
\hline Characteristic & HRWR & VEA1 & VEA2 & VEA3 \\
\hline Specific weight $\left(\mathrm{g} / \mathrm{cm}^{3}\right)$ & $1.05-1.10$ & 1.00 & 1.02 & 1.01 \\
\hline $\mathbf{p H}$ & $3-6$ & 6 & 6 & 8 \\
\hline Aspect & Liquid & Liquid & Gel & Liquid \\
\hline Solid content (\%) & - & 9.53 & 10.00 & 9.60 \\
\hline
\end{tabular}

In order to obtain a reference mix that would meet the extrudability requirements, a few different batches were tested according to the method proposed by [29], in which concrete filaments with 1 to $2 \mathrm{~cm}$ width are extruded for a minimum of $30 \mathrm{~cm}$ length. The material should keep its cohesion and shape to be considered extrudable, as shown in Figure $3 \mathrm{a}$. Figure $3 \mathrm{~b}$ shows the printing process of one sample.

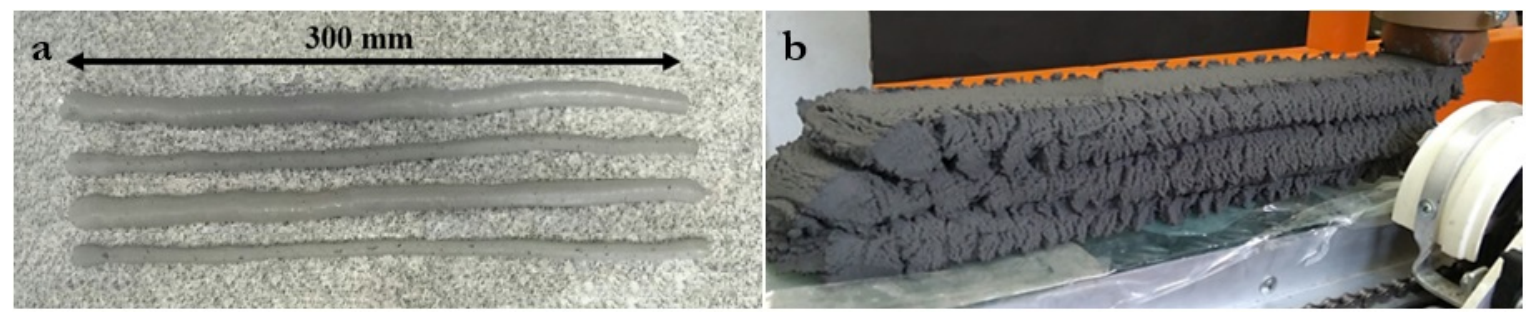

Figure 3. a) Extrudability test. b) Printed layers.

The established mixing procedure was the same for all mixes: dry materials were manually mixed prior to mechanical mixing was started and, thereafter, on the course of the first minute of mixing, they were gradually added to the mixing water, where the HRWR was already diluted. After that, the materials were mixed for 5 more minutes, 
put at rest for $1 \mathrm{~min}$ for the addition of the viscosity promoters, when the case, and proceeded to mix for 2 final minutes. The mixture velocity was fixed in 25rpm, in a Tedemix ML-03 mixer, equipped with a $\varnothing 80 \mathrm{~mm}$ cowls disc.

After the sample preparation, mixes were submitted to rheological tests, in order to evaluate the effect of the viscosity enhancing admixtures on the materials' yield strength over time, as well as to the materials' structuration rate.

\subsection{Rheological and complementary tests procedures}

Yield strength measurements were taken for all mixes at 10,45 and 90min after the addition of the cement to the water. For the rheological measurements, a Thermo Scientific HAAKE MARS III rheometer with Vane geometry was used.

The rotor was immersed into the mixes right after the mixture procedure was ended and kept at rest until the defined measurement times were reached. A new batch was made for each measurement that was taken. The tests were carried out maintaining a constant shear rate with angular velocity of $0,25 \mathrm{rpm}$. Results were obtained from the medium value of a pair of data, at each established resting time, and plotted as a function of the yield strength over time.

After the rheological tests, the consistency index was measured according to ABNT NBR 13276/2016 [30], at the same resting times established for the rheological measurements $(10,45$ and $90 \mathrm{~min})$, in order to evaluate the materials' fluidity loss over time. The test was carried out placing the material into the test recipient, and then left at rest until the established times were reached for testing.

The reaction kinetics of the mixtures were measured by isothermal calorimeter model TAM AIR (TA Instruments) of eight channels with controlled temperature of $23^{\circ} \mathrm{C}$ for 60 hours. Also, measurements for the fresh state specific weight, as well as the 28 days compressive strength, according to ABNT NBR 13278/2005 [31] and ABNT NBR 7215/1997 [32], respectively, were made.

\section{RESULTS AND DISCUSSIONS}

\subsection{Yield strength}

Figure 4 shows the yield strength obtained for all of the mixtures with 10, 45 and 90 minutes of rest. The increasing values over time observed is the result mostly of the flocculation processes that come from the interaction of colloidal particles inside the mixes, which can be also inferred from the calorimetry tests (see section 3.3), and also from the calcium silicate hydrates on the contact points between the cement particles that usually occur on cementitious materials [9], [14].

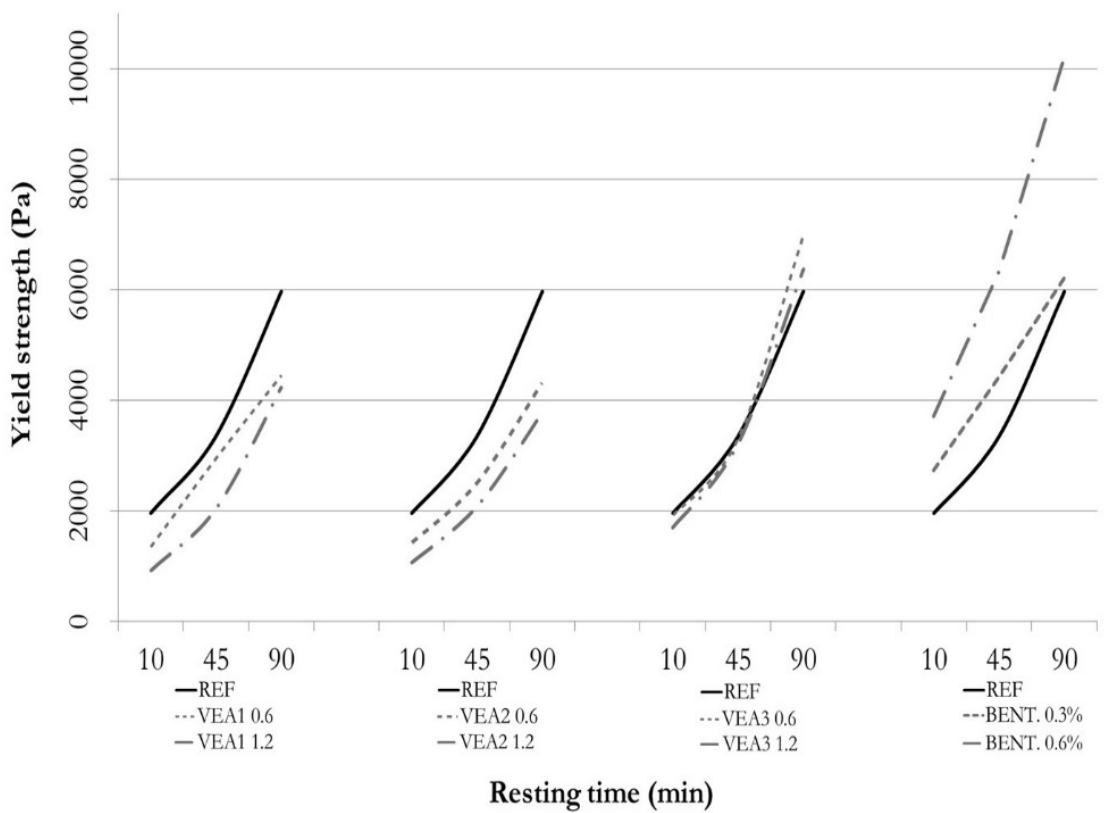

Figure 4. Yield strength evolution over time 
Regarding the mixtures with the polymeric VEAs, it can be said that:

1) VEA 1 and VEA2 were not able to increase, comparing to the reference mixture, the yield strength in any of the measured resting times.

2) For the mixture with VEA3, there was no significant variation from the reference mixture after up to 45 minutes, with a slightly increase at the 90 minutes measure.

This behavior may seem to go in opposition to what was expected, since the addition of the viscosity enhancing admixtures should increase the mixtures' viscosity and its yield strength. However, the mechanism in which each of this admixtures work can be affected both by the shear rate applied and the $\mathrm{w} / \mathrm{c}$ ratio. About the former, since the incorporation of the polymeric VEAs was made without discounting the water content of the solution, and their solid content was only approximately $10 \%$, the mixtures with VEA1, VEA2 and VEA3 had a slightly higher w/c ratio than the reference mixture, which can lead to viscosity reduction and yield strength decrease. This means that the three-dimensional polymeric structure expected to be formed due to the presence of such VEAs was not enough to produce an increase in the yield strength under this particular shear rate and in face of the $\mathrm{w} / \mathrm{c}$ difference.

It should be noted, nevertheless, that this does not mean that polymeric VEAs are always not suited for increasing the yield strength of printable concretes, because different applications subject the material to different shear rates. Besides, the water content of the polymeric solution can be subtracted from the mixture, if it is shown that to be the case. Regards to the chemical composition, there are many different commercially available polymeric VEAs, with different acting mechanisms - as discussed early on in this paper (see section 1.3) - which means that some of them may be better suited for some specific applications than others.

In contraposition to the mixes using the VEAs, the mixes that used bentonite on its composition, for both the lower $(0.3 \%)$ and the higher $(0.6 \%)$ percentages, showed an increase to the yield strength when compared to the reference mixture, for all measured resting times. The registered increase was up to $70 \%$ higher for the longer periods ( $90 \mathrm{~min}$ rest). It must be considered the fact that the incorporation of bentonite clay elevates the solid/liquid rate of the mixture, which alone can improve its viscosity and yield strength. But this behavior is not only due to the fact that the bentonite clay is a very fine material with high surface area, but also tend to form a thixotropic gel when dispersed in a liquid phase, which alters the rheological response of the mixture, as noted by previous works [33]. The results obtained here confirmed that the three-dimensional network was indeed formed by the bentonite presence, even with the dispersion happening on a cement-based matrix. This is of great value concerning $3 \mathrm{D}$ printing with concrete, because of the great gain in buildability.

\subsection{Structuration rate}

Table 4 shows the structuration rate values (Athix) of the investigated mixes. It is clear that the presence of VEA1 and VEA2 did not benefit the Athix value, lowering its measure of up to $32,6 \%$ of the original value (REF). On the other hand, the mixes with VEA 3 and bentonite clay presented structuration rates of up to $61,23 \%$ higher than the REF mix. In a previous study [34] involving the use of VEA in cement pastes, three different dosages of the admixture were tested, and as a result it was obtained that higher amounts of VEA would improve both the materials yield strength as well as the structuration rate. In that case, the obtained values for the Athix were slightly lower than the ones found here, firstly because said study wasn't carried for printability purposes, and secondly because the presence of the aggregates should improve the robustness of the material, resulting in higher yield strength. The increase on the structuration rates is an important asset for 3D printing applications because there is not only a need for high yield strength, but for a rapid increase to such values after the layer casting. The speed in which the structuration of the mixture under rest increases must be as higher as it is possible to print the next layers (to avoid cold joints), what varies with the available printer. That's why there is not a target value per se, but, in general, higher Athix values are preferable [6], [8]. In another recent work [35], it was also confirmed the effectiveness of clays in increasing the structuration rates of the mixes, there referred as the robustness of the material, when compared to mixes containing silica fume and viscosity modifying admixtures. In this case, superplasticizer was used to compensate the extremely higher yield strength in the mixes containing clays, in order to reach the same properties for printability purposes. However, according to [12], all produced mixes could be considered highly thixotropic. The BENT $0.6 \%$ mix produced the highest result for such a behavior, while VEA $1.2 \%$, the lowest.

Table 4 Structuration rate, mass density and entrained air of the mixes.

\begin{tabular}{cccccccccc}
\hline Property & REF & VEA1 0.6 & VEA1 1.2 & VEA2 0.6 & VEA2 1.2 & VEA3 0.6 & VEA3 1.2 & BENT 0.3 & BENT 0.6 \\
\hline A thix $_{\mathbf{~} \mathbf{P a} / \mathbf{s})}$ & 0.841 & 0.644 & 0.694 & 0.605 & 0.567 & 1.066 & 0.982 & 0.723 & 1.356 \\
\hline Mass density $\left(\mathbf{k g} / \mathbf{m}^{\mathbf{3}}\right)$ & 2040.4 & 1917.2 & 1899.6 & 2047.3 & 2038.3 & 2036.1 & 2022.4 & 2044.5 & 2065.1 \\
\hline Entrained air $\mathbf{( \% )}$ & 8.88 & 14.38 & 15.17 & 8.57 & 8.97 & 9.07 & 9.68 & 8.70 & 7.78 \\
\hline
\end{tabular}




\subsection{Isothermal calorimetry}

Figure 5 shows the heat flow released by the mixtures over time. It is possible to conclude that the induction periods (measured by the slope of the curves during the acceleration period) and the maximum heat release peaks have reached similar behaviors for all mixtures. It is evident that the different types and amounts of viscosity modifiers used have not produced significant alterations on the heat flow for the first hour, that is, they did not accelerate nor retard the hydration process of the mixtures in that period, meaning that potential modifications on the structuration rates, measured through the rheometry tests, were not due by an alteration on the cement hydration process.

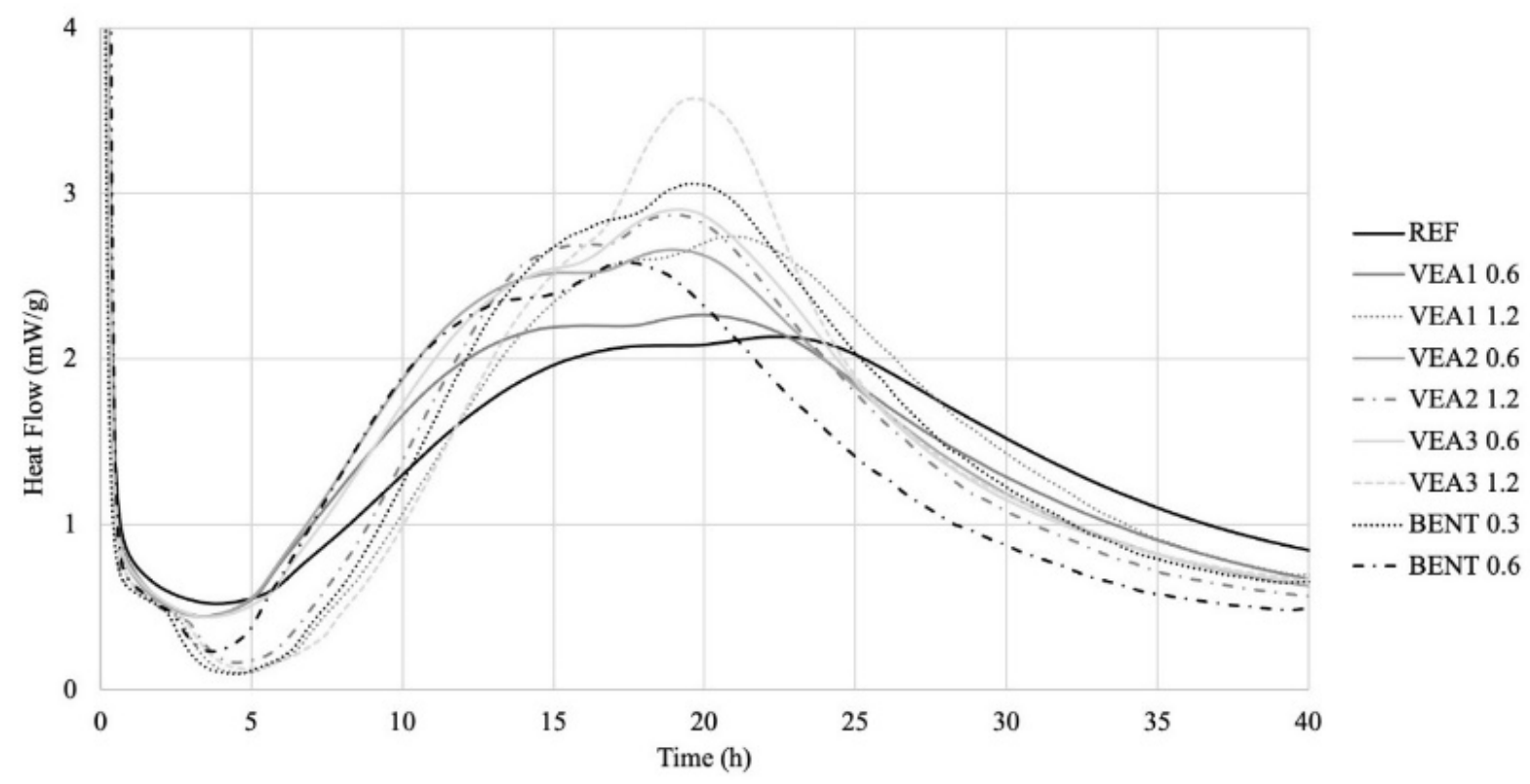

Figure 5. Heat flow over time.

\subsection{Consistency index}

Figure 6 shows that all mixes presented a decrease on the consistency index over time $(10 \mathrm{~min}, 45 \mathrm{~min}$ and $90 \mathrm{~min}$ resting times), as it was expected, being it a result of (a) the particle rearrangement; (b) the viscosity modifiers effect, or (c) as a result of the hydration products of the cement, even minimally. Through the results, it is possible to observe that VEA mixes have initially performed an increase on the flowability of the mixes, possibly caused by the change on the water/cement ratio due to the water content present on the VEAs. Such an increase was ceased for the longer waiting periods (90min resting time), where all mixes showed an increase on the consistency when compared to the REF mix. Previous studies with printable concretes have reported that using VEAs should result on the diminishing of the fluidity of the material on fresh state [36], [37], and that the consistency keeps increasing over time [36], as observed here. REF mix showed a $14 \%$ reduction on the consistency index during the 10 to $90 \mathrm{~min}$ interval, while VEAs produced a decrease of up to $38 \%$, and bentonites $40 \%$. When looking at the percentages between the same materials, it was not observed significant changes in any of the mixes. This result show that the incorporation of the different VEAs made the mixtures less susceptible to deformation over time, which is very useful to additive manufacturing applications.

\subsection{Mass density and entrained air}

The mass density and the entrained air values were measured for the fresh state of mixes. Table 4 shows these results. As it may be noted, most values were found to be similar to the REF mix, in exception of mixes VEA1 on both levels, which have shown a significant decrease in the mass density, as a result of a great air entrapment percentile. For mixes with VEA1 the entrained air values were up to $40 \%$ larger than the ones obtained by the REF mix, whereas mixes BENT showed the same amount or even slightly smaller values than REF. Usually, when looking into the VEAs action, it is not always expected for them to increase the air entrained content on cementitious mixtures [17], [38], although it might sometimes come as a secondary effect depending on the family of VEA that is used [17], like methylcellulose viscosity 
modifiers, for example [39]. In this case, the air entrainment would justify the lower performance of the VEA1 mixes when compared to the REF for the yield strength, structuration rate and even compressive strength obtained. For 3D printing, the incorporation of some air can be a good asset regards to the flowability of the mixture, but it is important that it does not negatively affect its mechanical performance. In this particular case, mixtures with higher amounts of entrained air (VEA1 0.6 and VEA1 1.2) performed among the worse results in the yield strength evaluation.

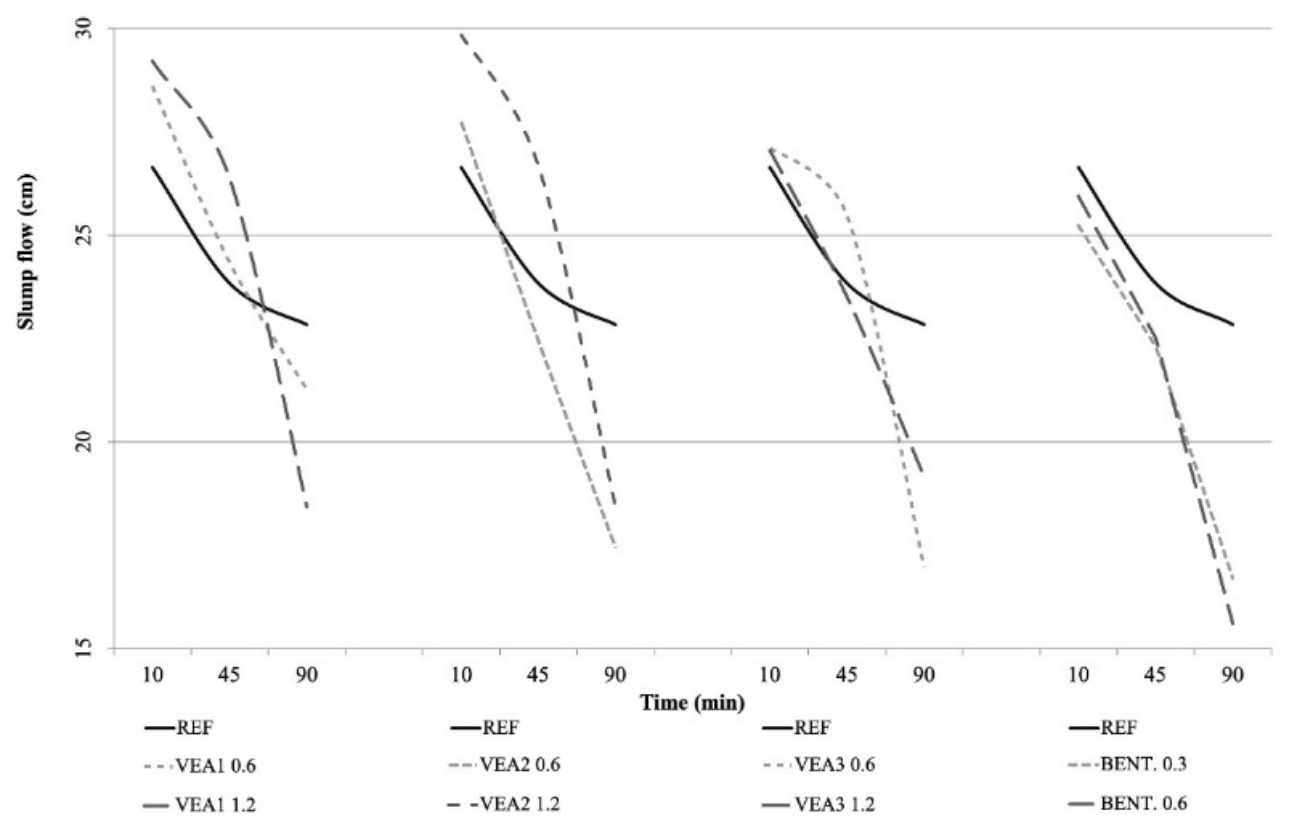

Figure 6. Consistency index.

\subsection{Compressive strength}

Figure 7 shows the compressive strength results on 28 days test. The results were statistically analyzed using variation analysis test (ANOVA), and the Fisher variation test. All mixes, except mixes VEA1, reached statistically the same value as the REF mix, which was 37.7MPa. Mix VEA1 1.2 had the worst result, $21 \%$ smaller than the REF mix, with only $29,6 \mathrm{MPa}$. This may be due to the higher air incorporation. The compressive strength of a concrete mixture for 3D printing varies with its application, therefore there isn't a specific range of compressive strength that should be aimed for. In this particular work, the aim was to see if the incorporation of VEAs would harm mechanical performance, which was not the case for the majority of the mixtures.

\subsection{Overall discussion}

For this study, viscosity-enhancing admixtures were used in order to benefit the structuration rate of the materials and to improve buildability by increasing the yield strength of the mixes. The consistency index test indicates that the modifiers did perform their job of promoting an increase in the cohesion of the mixture. However, the magnitude to which bentonite produced such effects, in both trials, was shown to be more expressive than that produced by polymeric VEAs.

It is important to state that the results make it evident that there is no direct numerical correlation between the consistency index and rheometry results, since the same range of consistency values may encompass distinct flow voltages.

The increased cohesion and yield strength, mainly presented by BENT mixtures, could be justified as an acceleration of the formation of cement hydration products. However, the calorimetry test proves that all the measurements performed occurred during the mixes dormant period, implying that the main effect was due to the physical flocculation phenomenon by internal arrangement of particles, regardless of the modifier used. When Bentonite clays were incorporated to the mixtures, the thixotropic effect can also be pointed as responsible for the structuration response. 


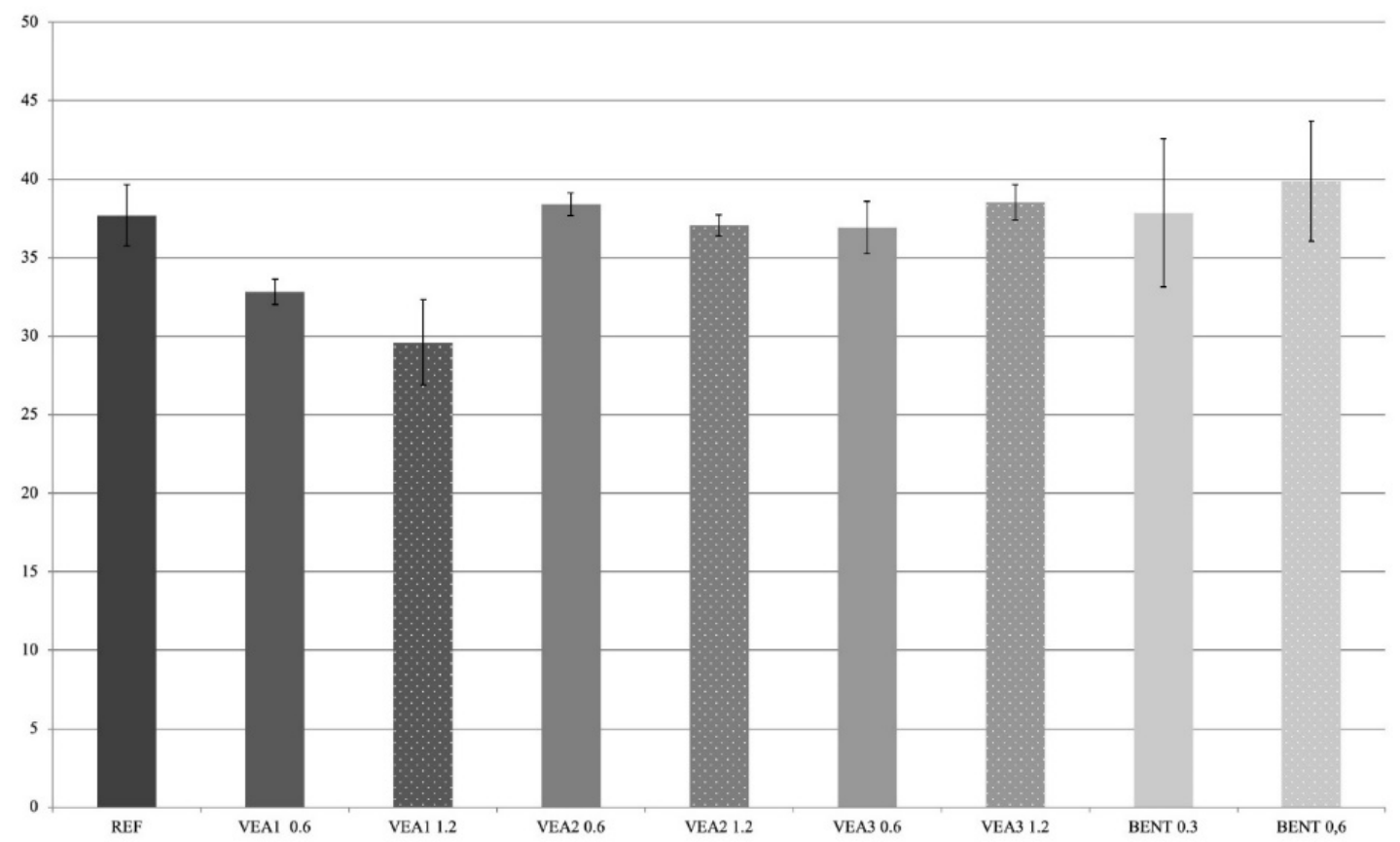

Figure 7. Compressive strength of all mixtures at age of 28 days.

Regarding the amounts of tested VEAs, the higher availability of the product in the mixture did not increase the cohesion and gain of the yield strength, except for the bentonites, where the higher content resulted in improved buildability. This could be due to (a) saturation of the VEAs into the mixture, (b) the adsorption difference with the cement particles, (c) its anionicity, (d) its molecular weight, (e) to an increase in the water/cement ratio (since the liquid admixtures were added without withdrawing the equivalent water amount of the mixture) and (f) due to an increase of the entrained air into the mixture (as it was the case with VEA1 0.6 an VEA1 1.2).

Furthermore, the presence of viscosity modifiers did not change the compressive strength values of the mixtures, except for mixtures VEA1. In this case, the higher content of incorporated air, confirmed by the fresh mass density test, justifies both the reduction in the compressive strength and also the lower performance of the product when compared to VEA2 and VEA3 in every other test.

The values of yield strength and structuration rate were higher for bentonite mixtures than those obtained by the other mixtures analyzed. The calorimetry test also proves that the improvement in the stiffness of the cementitious matrix by the presence of clay is not due to the increase of the formation of cement hydration products. Therefore, the structuration phenomenon is attributed to the internal arrangement, and especially to the formation of thixotropic gel, the formation of a three-dimensional network, free water retention and ionic attraction of the particles' effects caused by this type of material.

The results point to the technical feasibility of the use of viscosity modifiers in favor of the load bearing capacity of concrete suitable for 3D-printing, due to the increased cohesion. It should be noted, however, that not all types of VEAs would be capable of delivering the same effect, while bentonites would be the best of the options, showing a better behavior than any other modifier.

\section{CONCLUSIONS}

The study set to investigate the effect of three commercial viscosity enhancing admixtures and bentonite clay over the structuration rate of $3 \mathrm{D}$ printable concretes allows to conclude that:

- VEAs show potential for increasing the cohesion and buildability of concretes for 3D-printing;

- It was not possible to determine a direct relationship between the structuration rate, cohesion of the mixture and its buildability; 
- With due control in the content, the presence of bentonite clay in concrete for 3D printing does not influence negatively the values of compressive strength;

- The use of bentonite clays in concrete mixes for 3D printing proved to be very effective in promoting cohesion and increasing buildability, being a field of research with imminent potential.

\section{ACKNOWLEDGEMENTS}

The authors would like to thank CNPq for its financial support provided through Project No. 310925/2016-9, CAPES for supporting the researchers with scholarships and FAPESC for its partnership throughout this work.

\section{REFERENCES}

[1] P. Wu, J. Wang, and X. Wang, "A critical review of the use of 3-D printing in the construction industry," Autom. Construct., vol. 68, pp. 21-31, Aug. 2016.

[2] Z. Malaeb, H. Hachem, A. Tourbah, T. Maalouf, N. E. Zarwi, and F. Hamzeh, "3D concrete printing: Machine and mix design," Int. J. Civ. Eng., vol. 6, no. 6, pp. 14-22, June 2015.

[3] T. Wangler et al., "Digital concrete: Opportunities and challenges," RILEM Tech. Lett., vol. 1, pp. 67-75, Oct. 2016.

[4] G. Ma and L. Wang, "A critical review of preparation design and workability measurement of concrete material for largescale 3D printing," Front. Struct. Civ. Eng., vol. 12, no. 3, pp. 1-19, Aug. 2017.

[5] J. Buchli et al., "Digital in situ fabrication-Challenges and opportunities for robotic in situ fabrication in architecture, construction, and beyond," Cement Concr. Res., vol. 112, pp. 66-75, Oct. 2018.

[6] N. Roussel, "Rheological requirements for printable concretes," Cement Concr. Res., vol. 112, pp. 76-85, Oct. 2018.

[7] D. Marchon et al., "Hydration and rheology control of concrete for digital fabrication: Potential admixtures and cement chemistry," Cement Concr. Res., vol. 112, pp. 96-110, Oct. 2018.

[8] A. Perrot, D. Rangerard, and A. Pierre, "Structural built-up of cement-based materials used for 3D printing extrusion techniques," Mater. Struct., vol. 49, pp. 1213-1220, Apr. 2016.

[9] N. Roussel, G. Ovarlez, S. Garrault, and C. Brumaud, "The origins of thixotropy of fresh cement pastes," Cement Concr. Res., vol. 42, pp. 148-157, Jan. 2012.

[10] A. Yahia, S. Mantellato, and R. J. Flatt "Concrete rheology: A basis for understanding chemical admixtures," in Science and Technology of Concrete Admixtures (Series in Civil and Structural Engineering 59), P. C. Aïtcin, R. J. Flatt, Orgs., United Kingdom: Woodhead Publishing, 2015, pp. 97-127.

[11] L. Reiter et al., "The role of early age structural build-up in digital fabrication with concrete," Cement Concr. Res., vol. 112, pp. 8695, June 2018.

[12] N. Roussel and F. Cussigh, "Distinct-layer casting of SCC: The mechanical consequences of thixotropy," Cement Concr. Res., vol. 38, pp. 624-632, May 2008.

[13] N. Roussel, "A thixotropy model for fresh fluid concretes: Theory, validation and applications," Cement Concr. Res., vol. 36, pp. 1797-1806, Sept 2006.

[14] P. C. Aitcin, "The importance of the water-cement and water-binder ratios," in Science and Technology of Concrete Admixtures (Woodhead Publishing Series in Civil and Structural Engineering, 59). P. C. Aïtcin, and R. J. Flatt, Orgs., United Kingdom: Woodhead Publishing, 2015, pp. 03-14.

[15] S. G. Gauffinet, "The rheology of cement during setting," in Understanding the Rheology of Concrete, N. Roussel, Org., Cambridge, UK: Elsevier, 2012.

[16] Experts for Specialized Construction and Concrete Systems. Guidelines for Viscosity Modifying Admixtures for Concrete. Belin, Germany: EFCA, 2006.

[17] K. H. Khayat, "Viscosity-enhancing admixtures for cement-based materials - An overview," Cement Concr. Compos., vol. 20, pp. 171-188, 1998.

[18] A. Leemann and F. Winefeld, "The effect of viscosity modifying agents on mortar and concrete," Cement Concr. Compos., vol. 29, pp. 341-349, 2007.

[19] H. Bessaies-Bey, "Polymères et propriétés rhéologiques d'une pâte de ciment: une approche physique générique," Ph.D. dissertation, Univ. Paris Est, France, 2015. [Online]. Available: http://www.theses.fr/2015PEST1042.

[20] R. E. Grim, Applied Clay Mineralogy. New York: Mcgraw-hill Book Company, Inc., 1962.

[21] P. S. Santos, Tecnologia de Argilas Aplicada às Argilas Brasileiras, Vol. 1 e 2, São Paulo: Editora Edgard Blucher Ltda., 1975. 
[22] H. Van Olphen, Clay Colloid Chemistry: For Clay Technologists, Geologists, and Soil Scientists, 2. ed. Malabar, FL: Krieger Publishing Company, 1991.

[23] J. K. Mitchell and K. Soga, Fundamentals of Soil Behavior, 3rd ed. Hoboken, NJ: John Wiley \& Sons, 2005.

[24] F. Galindo-Rosales and F. Rubio-Hernandez, "Structural breakdown and build-up in bentonite dispersions," Appl. Clay Sci., vol. 33, no. 2, pp. 109-115, July 2006. http://dx.doi.org/10.1016/j.clay.2006.03.011.

[25] M. Wu and Y. Adachi, "Effects of electrolyte concentration and pH on the sedimentation rate of coagulated suspension of sodium montmorillonite," Colloids and Surf. A: Physicochem. Eng. Asp., vol. 506, pp. 686-693, Oct. 2016. http://dx.doi.org/10.1016/j.colsurfa.2016.07.027

[26] Y. Zhang, Y. Zhang, G. Liu, Y. Yang, M. Wu and B. Pang, "Fresh properties of a novel 3D printing concrete ink," Constr. Build. Mater., vol. 174, pp. 263-271, June 2018. http://dx.doi.org/10.1016/j.conbuildmat.2018.04.115.

[27] D. Plee et al., "Microstructure, permeability and rheology of bentonite-cement slurries," Cement Concr. Res., vol. 20, no. 1, pp. 45-61, Jan. 1990.

[28] Associação Brasileira de Normas Técnicas, NBR 5736: Cimento Portland Pozolânico. Rio de Janeiro: ABNT, 1991.

[29] T. T. Le, Austin S. A., Lim S., Buswell R. A., Gibb A. G. F., and Thorpe T., "Mix design and fresh properties for high-performance printing concrete," Materials and Structures, vol. 45, no. 8, pp. 1221-1232, Jan. 2012. http://dx.doi.org/10.1617/s11527-012-9828-z.

[30] Associação Brasileira de Normas Técnicas. NBR 13276: Argamassa para Assentamento e Revestimento de Paredes e Tetos - Preparo da Mistura e Determinação do Índice de Consistência, 2005.

[31] Associação Brasileira de Normas Técnicas. NBR 13278: Argamassa para Assentamento e Revestimento de Paredes e Tetos - Determinação da Densidade de Massa e do Teor de Ar Incorporado, 2005.

[32] Associação Brasileira de Normas Técnicas. NBR 7215: Cimento Portland: Determinação da Resistência à Compressão, 1996.

[33] Abu-Jdayi, B., "Rheology of sodium and calcium bentonite-water dispersions: Effect of electrolytes and aging time," International Journal of Mineral Processing, vol. 98, no. 3-4, pp. 208-213, Mar. 2011. http://dx.doi.org/10.1016/j.minpro.2011.01.001.

[34] M. Thiedeitz, T. Kränkel, and C. Gehlen, "Thixotropy-Dependent Form Filling Ability of Cement Paste. in Rheology and Processing of Construction Materials. Cham: Springer, 2019. pp. 273-280.

[35] A. V. Rahul, M. Santhanam, H. Meena, and Z. Ghani, “3D printable concrete: Mixture design and test methods,” Cement Concr. Res., vol. 97 , pp. 13-23, Mar. 2019. http://dx.doi.org/10.1016/j.cemconcomp.2018.12.014.

[36] Z. Li, L. Wang, and G. Ma, "Method for the enhancement of buildability and bending resistance of three-dimensional-printable tailing mortar," in 3 D Concrete Printing Technology, 1st ed., J.G. Sanjayan, A. Nazari, and B. Nematollahi, Eds., Amsterdam, The Netherlands: Elsevier, 2019. pp. 161-180.

[37] M. Rubio, M. Sonebi, and S. Amziane, "Fresh and rheological properties of 3d printing bio-cement-based materials," 2nd Int. Conf. Bio-based Build Mater., June 2017.

[38] M. Lachemi, K. M. A. Hossain, V. Lambros, P. C. Nkinamubanzi, and N. Bouzoubaâ, "Self-consolidating concrete incorporating new viscosity modifying admixtures," Cement Concr. Res., vol. 34, no. 6, pp. 917-926, June 2004.

[39] B. Łaźniwska-Piekarczyk, "The type of air-entraining and viscosity modifying admixtures and porosity and frost durability of high performance self-compacting concrete," Constr. Build. Mater., vol. 40, pp. 659-671, Mar 2013.

Author contributions: JAH, APR, and LCQ designed and performed the experiments, analyzed the results and wrote the manuscript. WLR conceived the original idea and supervised the project. All authors provided critical feedback and helped shape the research, analysis and manuscript.

Editors: Bernardo Tutikian, José Luiz Antunes de Oliveira e Sousa, Guilherme Aris Parsekian. 